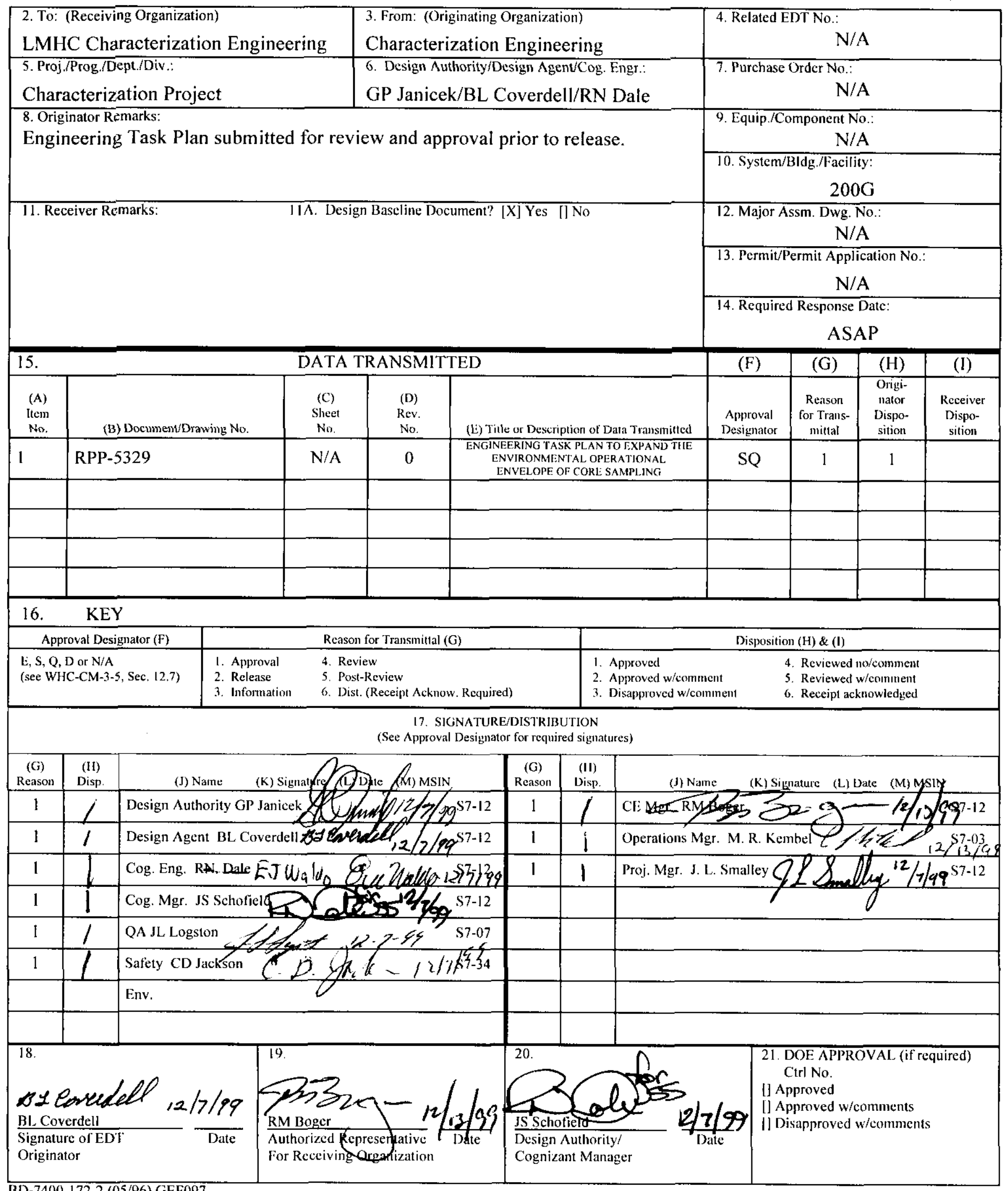




\section{ENGINEERING TASK PLAN TO EXPAND THE ENVIRONMENTAL OPERATIONAL ENVELOPE OF CORE SAMPLING}

R. M. Boger

Prepared by Lockheed Martin Hanford Company

2400 Stevens

Richland, WA 99352

$9921 / 4047$

U.S. Department of Energy Contract DE-AC06-96RH 13200 dzist-44.

EDT/ECN: 623358

UC: 2070

Org Code: 74900

B\&R Code: EW3120074

Charge Code: CACN: $102254 \quad$ COA: $\mathrm{B} 000$

Total Pages: 910

dz

Key Words: Core Sampling, Engineering Task Plan (ETP), Alternative Generation and Analysis (AGA)

Abstract: This Engineering Task Plan authorizes the development of an Alternative Generation and Analysis (AGA). The AGA will determine how to expand the environmental operating envelope during core sampling operations.

TRADEMARK DISCLAIMER. Reference herein to any specific commercial product, process, or service by trade name, trademark, manufacturer, or otherwise, does not necessarily constitute or imply its endorsement, recommendation, or favoring by the United States Government or any agency thereof or its contractors or subcontractors.

Printed in the United States of America. To obtain copies of this document, contact: Document Control Services, P.O. Box 950, Mailstop 116-08, Richland WA 99352, Phone (509) 372-2420; Fax (509) 376-4989.
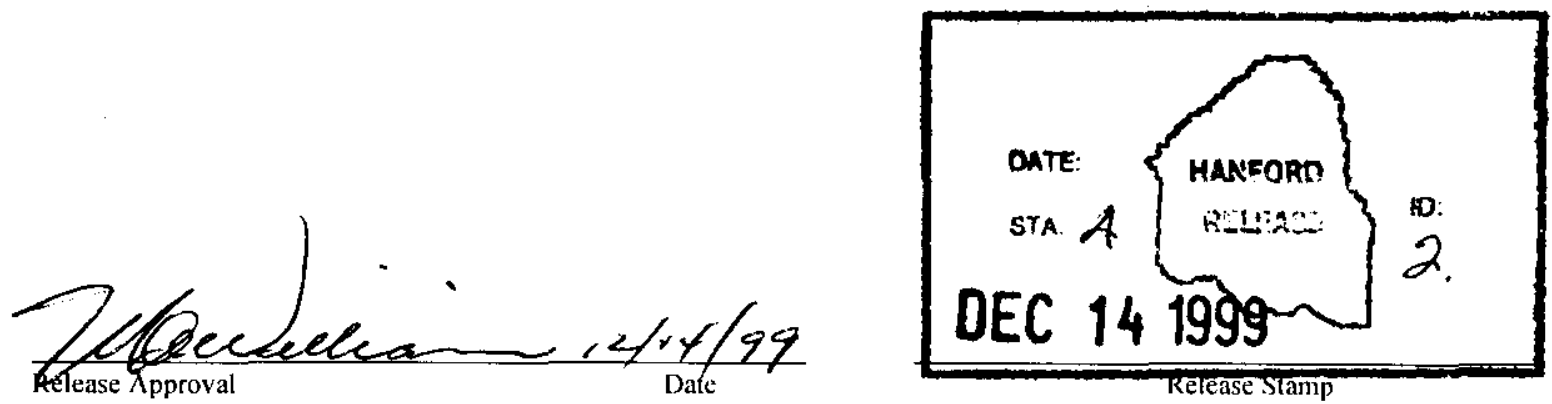


\section{ENGINEERING TASK PLAN TO EXPAND THE ENVIRONMENTAL OPERATIONAL ENVELOPE OF CORE SAMPLING}

Prepared for Lockheed Martin Hanford Corporation

Characterization Engineering Group

By

B. L. Coverdell

COGEMA Engineering Corporation

December, 1999 


\section{TABLE OF CONTENTS}

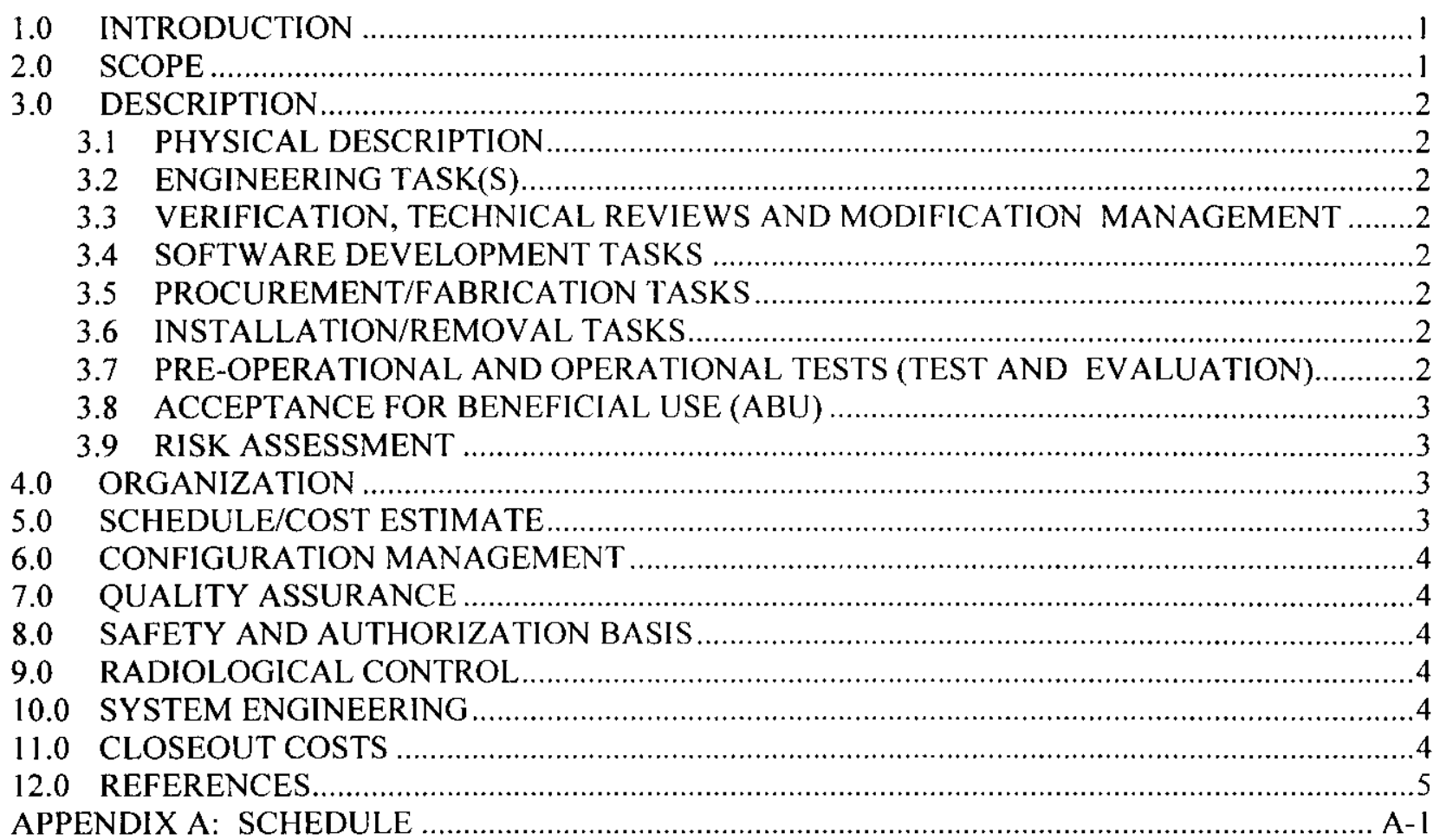




\section{ENGINEERING TASK PLAN TO EXPAND THE ENVIRONMENTAL OPERATIONAL ENVELOPE OF CORE SAMPLING}

\subsection{INTRODUCTION}

This Engineering Task Plan (ETP) addresses the development of an Alternative Generation and Analysis (AGA) for determining how to expand the environmental operating envelope during core sampling operations.

Halting of core sampling operations due to environmental conditions such as wind, precipitation and temperature is currently based on information obtained from several documents. Overall, the controlling environmental conditions are wind and temperature (cold and high heat). The guiding document for wind is Standing Order \#TWO-99-19, LMHC 1999g. For air temperature, there are two documents, one for high heat and one for cold. The controlling document for high heat is Heat Stress Control, LMHC 1999d and for cold air temperature, the governing document is the Tank Farms Health and Safety Plan, LMHC $1999 \mathrm{c}$. These three documents give guidance to the shift manager and the Person in Charge (PIC) to help him or her to make the safest decision possible on when to work or not to work or how long to work, i.e. when breaks should be taken and for how long.

When the shift manager and/or PIC make the decision to work or not based on environmental conditions, they will always err on the conservative side. During hot summer days this results in stopping daytime core sampling operations and it can also result in partial shut down of swing shift operations, swing shift ends up waiting for the temperatures to drop enough to work. The result is graveyard shift becomes the only productive shift. During winter, extreme cold conditions will also cause operations to shut down reducing productivity.

It is anticipated that the AGA will demonstrate the need for development of a specialty enclosure for use at the riser interface where the core sample truck drill head and shielded receiver attach to the drill string.

\subsection{SCOPE}

The scope of this ETP is the completion of an AGA that details the best solution, if any, to increase the environmental operating envelope for core sampling. The AGA shall consider the following environmental factors;

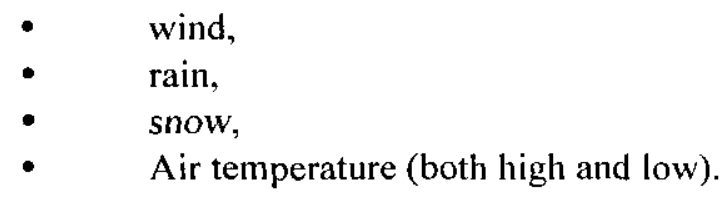

This ETP is the management plan document for accomplishing the identified task. It is anticipated that the completion of the task will result in an increase in scope. Any such change in scope will require a revision to this ETP. 
RPP-5329, Rev. 0

\subsection{DESCRIPTION}

\subsection{PHYSICAL DESCRIPTION}

The result of this task will be the completion of an AGA as required by the River Protection Project Fiscal Year 2000 Multi-Year Work Plan (LMHC 1999e). The completion of this task will comply with, Alternative Generation and Analysis (LMHC 1999a).

\subsection{ENGINEERING TASK(S)}

This task will result in the preparation of an AGA per LMHC 1999a.

\subsection{VERIFICATION, TECHNICAL REVIEWS AND MODIFICATION MANAGEMENT}

Completion of the AGA does not require any design drawings, installation drawings, design analyses and/or fabrication, therefore; design verification and/or modification management is not required per Design Verification (LMHC 1999b). Technical review of the AGA will be completed per LMHC 1999b.

\subsection{SOFTWARE DEVELOPMENT TASKS}

There are no software development tasks associated with this task.

\subsection{PROCUREMENT/FABRICATION TASKS}

There are no procurement or fabrication tasks associated with this task; however, future activities may require support for procurement and fabrication. Any changes in scope, such as the requirement for procurement and/or fabrication, will be addressed by a revision to this ETP.

\subsection{INSTALLATION/REMOVAL TASKS}

There are no installation or removal tasks associated with this task; however, future activities may require installation and removal of the first item. Any changes in scope, such as installation and/or removal tasks, will be addressed by a revision to this ETP.

\subsection{PRE-OPERATIONAL AND OPERATIONAL TESTS (TEST AND EVALUATION)}

There are no pre-operational or operational tests associated with this task; however, future activities may require pre-operational and/or operational testing. Any changes in scope, such as pre-operational and/or operational testing, will be addressed by a revision to this ETP. 


\subsection{ACCEPTANCE FOR BENEFICIAL USE (ABU)}

This task will not require the completion of an $\mathrm{ABU}$; however, future activities may require the completion of an ABU. Any changes in scope, such as the requirement to complete an ABU, will be addressed by a revision to this ETP.

\subsection{RISK ASSESSMENT}

There are no risks associated with completion of the AGA; however, future activities may require the completion of a risk assessment. Any changes in scope, such as the requirement to complete a risk assessment, will be addressed by a revision to this ETP.

\subsection{ORGANIZATION}

Responsibilities are assigned to various organizations as identified below:

COGEMA Engineering Corporation will provide task management, engineering support, and design services support as outlined in section 3.2.

Responsible Manager: J. L. Smalley

Responsible Engineer: B. L. Coverdell

Lockheed Martin Hanford Corporation (LMHC), Characterization Engineering will provide funding and overall task management:

Responsible Manager: R. M. Boger

LMHC, Characterization Engineering will also provide Cognizant Engineer support for document review and Un-reviewed Safety Question (USQ) screening preparation.

Responsible Manager: J. S. Schofield

Responsible Engineer: R. N. Dale

LMHC provide Design Authority support.

Characterization Project System Design Authority: G. P. Janicek

LMHC, Characterization Project Operations will provide the appropriate Operator, Radiological Control, Industrial Safety and Maintenance resources for consultation in development and review of AGA.

Characterization Project Operations: M. R. Kembel

\subsection{SCHEDULE/COST ESTIMATE}

The schedule for completion of the AGA is shown in Appendix A. The estimated cost is $\$ 18,000$ or 200 man-hours. 


\subsection{CONFIGURATION MANAGEMENT}

The AGA shall be released into the Hanford Document Control System as a supporting document. Configuration of the AGA shall comply with requirements in Engineering Document Change Control Requirements (LMHC 1999d).

\subsection{QUALITY ASSURANCE}

Quality Assurance will be included in the development of the AGA and will review and approve the AGA.

\subsection{SAFETY AND AUTHORIZATION BASIS}

Safety will be included in the development of the AGA and will review and approve the AGA.

\subsection{RADIOLOGICAL CONTROL}

Radiological Control will be included in the development of the AGA and will review and approve the AGA.

\subsection{SYSTEM ENGINEERING}

This ETP defines the work required to complete an AGA for identifying and determining the optimum solution for expanding the environmental operating envelope for core sampling activities. This subtask is currently covered under the Work Breakdown Structure (WBS) 1.1.1.1.1.3.1.13 with a Cost Account Charge Number (CACN) of 102254 and a Code Of Account (COA) of B000. Any major changes will be made to the WBS through the change request process (CR-TWRS-98-024).

\subsection{CLOSEOUT COSTS}

No closeout costs are associated with this task; however, future activities may have associated closeout costs. Any changes in scope will be addressed by a revision to this ETP. 


\subsection{REFERENCES}

LMHC, 1999a, HNF-IP-0842, RPP Administration, Volume IV, Engineering, Section 3.3" Revision 1, Alternative Generation and Analysis, Lockheed Martin Hanford Corporation, Richland, Washington.

LMHC, 1999b, HNF-IP-0842, RPP Administration, Vol. IV, Engineering, Section 4.24, Revision 0b, Design Verification, Lockheed Martin Hanford Corporation, Richland, Washington.

LMHC, 1999c, HNF-SD-WM-HSP-002, Rev. 3B, Tank Farms Health and Safety Plan, Lockheed Martin Hanford Corporation, Richland, Washington.

LMHC, 1999d, LMH-PRO-121, Rev. 0, Heat Stress Control, Lockheed Martin Hanford Corporation, Richland, Washington.

LMHC, 1999e, LMH-PRO-440, Rev. 0, Engineering Document Change Control Requirements, Lockheed Martin Hanford Corporation, Richland, Washington.

LMHC, 1999f, HNF-SP-1230, Revision 2 (draft), River Protection Project Fiscal Year 2000 Multi-Year Work Plan, WBS 1.1, Lockheed Martin Hanford Corporation, Richland, Washington.

LMHC, 1999g, Standing Order \#TWO-99-19, Precautions for High Wind Conditions, Lockheed Martin Hanford Corporation, Richland, Washington. 
RPP-5329, Rev. 0

APPENDIX A: SCHEDULE

Page A-1 
RPP-5329, Rev. 0

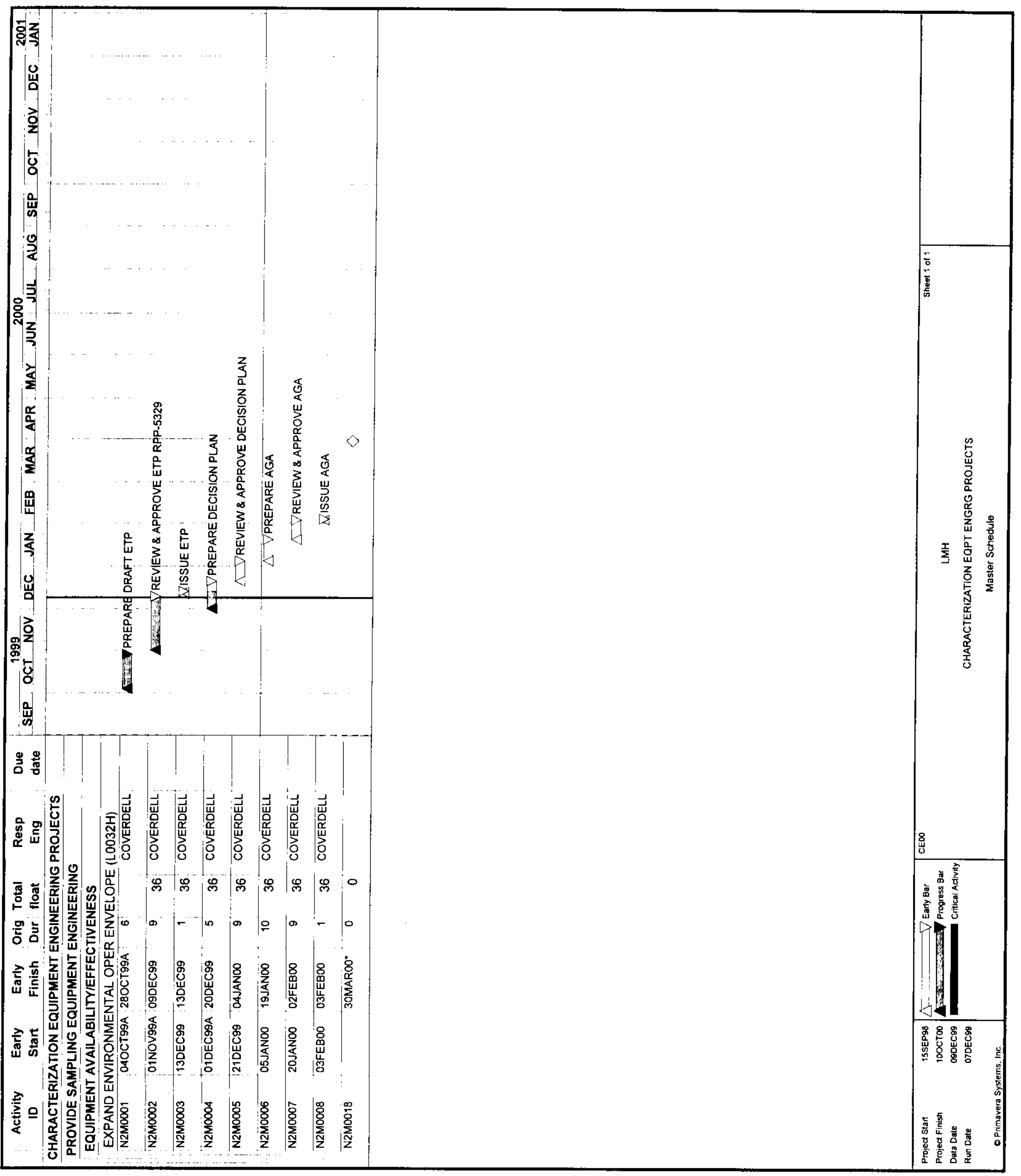

